\title{
ICD-10 Procedure Coding System
}

National Cancer Institute

\section{Source}

National Cancer Institute. ICD-10 Procedure Coding System. NCI Thesaurus. Code C132307.

An international system of medical classification used for procedural coding. 